KRZYSZTOF STACHOWIAK

Uniwersytet im. Adama Mickiewicza w Poznaniu

\title{
Ewolucja przemysłu zaawansowanej technologii i sektora teleinformatycznego (ICT) w Finlandii
}

W ostatniej dekadzie XX wieku Finlandia przebojem weszła do ścisłej czołówki państw rozwijających gospodarkę opartą na wiedzy, stając się tym samym jednym z liderów społeczeństwa informacyjnego. Spektakularnym tego przejawem może być to, że w rankingach najbardziej rozwiniętych technologicznie krajów, a także najbardziej konkurencyjnych gospodarek Finlandia zajmowała czołowe miejsca (wyprzedzając m.in. Stany Zjednoczone). Tak zwany fiński model społeczeństwa informacyjnego (Castells, Himanen 2002) charakteryzuje się: (1) rozbudowanym i ugruntowanym systemem instytucjonalnym, (2) wysokim stopniem adaptacji do nowych wyzwań gospodarczych i politycznych, (3) znaczącymi inwestycjami w wiedzę i kapitał ludzki, (4) egalitarnym społeczeństwem z silnie rozwiniętym państwem opiekuńczym, (5) wysokim rozwojem przemysłu zaawansowanych technologii i systemu wspierania badań technologicznych. Dynamiczny rozwój przemysłów high-tech był i ciągle jest motorem napędzającym fińską gospodarkę. To dzięki temu Finlandia w ciagu zaledwie kilku dekad przestała być krajem rolniczym, a stała się symbolem nowoczesności. Od połowy lat 90. XX w. rola przemysłu zaawansowanych technologii i sektora ICT rosła, by w pierwszych latach XXI w. stanowić dziesiątą część fińskiego PKB i jedną piątą krajowego eksportu.

W artykule podjęto się próby przedstawienia ogólnych przemian, jakie zaszły w gospodarce fińskiej, uwypuklając rolę zaawansowanych technologii w tych procesach. Ponieważ rozwój określonej części gospodarki nie odbywa się niezależnie, istotne znaczenie ma kontekst, w jakim proces ten zachodzi. Rozwój przemysłu zaawansowanej technologii i sektora ICT w Finlandii był możliwy dzięki splotowi określonych czynników, a przede wszystkim dzięki specyficznym cechom rodzimej gospodarki.

\section{ZMIANY KONKURENCYJNOŚCI GOSPODARKI I PRZEMYSŁU FINLANDII W XIX I XX WIEKU}

Ewolucję przemysłu zaawansowanych technologii i sektora teleinformatycznego w Finlandii można przedstawić w oparciu o model rozwoju gospodarki Portera (1990). W tej koncepcji uzyskanie przewagi konkurencyjnej danej branży lub gospodarki odbywa się dzięki czterem czynnikom determinującym. Do tak zwanego „diamentu Portera” zalicza 
się: wyposażenie w czynniki wytwórcze, czynniki popytowe, odpowiednią strukturę branżową, warunki tworzenia, organizacji i zarządzania przedsiębiorstwem. Na podstawie tych elementów charakteryzujących gospodarkę można określić etap jej ekonomicznego rozwoju. Porter (1990, s. 543-573) wyróżnił trzy takie etapy, w których wykorzystywane są odpowiednie przewagi konkurencyjne. Przewagi te dotyczą firm danego kraju w odniesieniu do firm innych krajów, a więc odnoszą się do konkurencyjności międzynarodowej. W każdym ze stadiów konkurencyjność oparta jest na innych czynnikach: w pierwszym na czynnikach wytwórczych (praca i surowce), w drugim na inwestycjach, w trzecim na innowacjach i wiedzy. Z koncepcji Portera wynika, że ścieżka ewolucyjnego rozwoju branży lub gospodarki oznacza przenoszenie przewag komparatywnych od towarów pracochłonnych i surowcowochłonnych do towarów kapitałochłonnych, a następnie do produktów charakteryzujących się wysokim stopniem innowacyjności i nowoczesnej technologii. Droga ta, obejmująca różne fazy rozwoju gospodarki, składa się z trzech zasadniczych etapów, w których gospodarka oparta jest na (1) zasobach i surowcach, (2) inwestycjach i (3) wiedzy. W Finlandii ten ostatni etap związany był z pojawieniem się zaawansowanych technologii, zwłaszcza technologii informacyjno-komunikacyjnych (ICT) pod koniec lat 80. Jednak wytwarzanie technologii już wcześniej związane było dość silnie z tradycyjnymi przemysłami drzewnym i metalowym.

W gospodarce opartej na zasobach przewaga konkurencyjna rozwijających się dopiero firm jest wynikiem działania czynników wytwórczych, a więc surowców i pracy. W Finlandii stadium to rozpoczęło się w połowie XIX w. i trwało do lat 30. XX w. Podstawowe czynniki wytwórcze w fińskiej gospodarce stanowiły obfite zasoby drewna, kopaliny w postaci minerałów i systemy wodne (jeziorno-rzeczne), które dostarczały energii dzięki elektrowniom wodnym oraz stanowiły podstawę transportu wodnego. Gospodarka funkcjonowała głównie dzięki wydobyciu i wykorzystywaniu tych właśnie zasobów - w bardzo niewielkim stopniu produkowano dobra inwestycyjne, a większość wytwarzanych produktów miała standaryzowany charakter. Firmy stosowały technologie wytwarzane w innych krajach, co sprawiało, że transfer technologii był istotny, choć niewiele firm posiadało bezpośredni kontakt z firmami zagranicznymi. Niemniej jednak gospodarka była do pewnego stopnia uzależniona od sytuacji w innych krajach, zwłaszcza kiedy rozwinięto intensywny eksport drewna i produktów drzewnych. Ta ekspansja umożliwiła jednak rozwój rodzimych firm i pozwoliła stworzyć podstawę do ich dalszego, trwałego wzrostu. Widoczne było to w rosnącej tendencji do inwestowania zysków ze sprzedaży. Rozwój ten zbiegł się w czasie z intensywną budową przez państwo sieci infrastruktury i struktur instytucjonalnych, zwłaszcza systemów edukacji i finansowego (Ojala i in. 2006).

Kolejny etap rozwoju przewagi konkurencyjnej firm danego kraju związany jest w głównej mierze z możliwościami i chęciami firm do poszerzania zakresu swoich działań poprzez intensywne inwestycje w nowoczesne i wydajne systemy produkcji. Wówczas firmy zainteresowane są pozyskaniem możliwie najlepszych technologii. A te, pozyskiwane głównie z zagranicy, są nie tylko szeroko wykorzystywane, ale również modyfikowane i ulepszane dla konkretnych potrzeb firm. Dlatego też firmy adaptują i rozwijają innowacje wytworzone gdzie indziej. Ciągle konkurują względnie standaryzowanymi produktami, które jednak są wytwarzane efektywniejszymi sposobami. W Finlandii ten etap rozwoju związany był z okresem powojennym i trwał do końca lat 80 . Obejmował on zwłaszcza inwestycje w działalności związane z obróbką i przetwarzaniem drewna, a więc przede wszystkim w przemyśle papierniczym. Rozwijano także przemysł energetyczny i elektroniczny oraz działalności inżynieryjno-techniczne. To wszystko miało na celu czerpanie jak największych korzyści 
z rozwijanych branż. Wzrastająca w tym czasie konsumpcja i ekstensywna polityka redystrybucji dochodu wymagały podjęcia określonych działań, które wspomogłyby dalszy rozwój inwestycji. Polityka przemysłowa i gospodarcza była więc nastawiona na te elementy, które mogły zachęcić do inwestycji. Stosowano szereg zachęt i ulg podatkowych, a także odpowiednią politykę kursową, która miała uczynić eksport jeszcze bardziej opłacalnym.

Taki charakter gospodarki utrzymywał się do końca lat 80 . Finlandia była tradycyjne krajem o kapitałochłonnej produkcji i wysokim poziomie inwestycji (ryc. 1). Do roku 1990 wielkość inwestycji w relacji do PKB wahała się między 25\% a 30\%. W latach 1991-1994 wielkość ta spadła o 12 punktów procentowych, by wzrosnąć do poziomu blisko 20\% w drugiej połowie lat 90., a więc w okresie szybkiego wzrostu gospodarczego. Po tym okresie wskaźnik ten ustabilizował się i obecnie inwestycje stanowią nie więcej niż jedną piątą fińskiego PKB. Odpowiada on temu, co można zaobserwować w krajach UE, USA i Japonii. Fińska produkcja, począwszy od lat 90., stała się względnie mniej kapitałochłonna, co związane jest z dynamicznym rozwojem sektora usługowego oraz przemysłów zaawansowanej technologii, w szczególności elektronicznego. Również ze względu na procesy globalizacji i związane z nimi zmiany strukturalne w gospodarce wykorzystanie kapitału w przedsiębiorstwach jest obecnie bardziej efektywne.

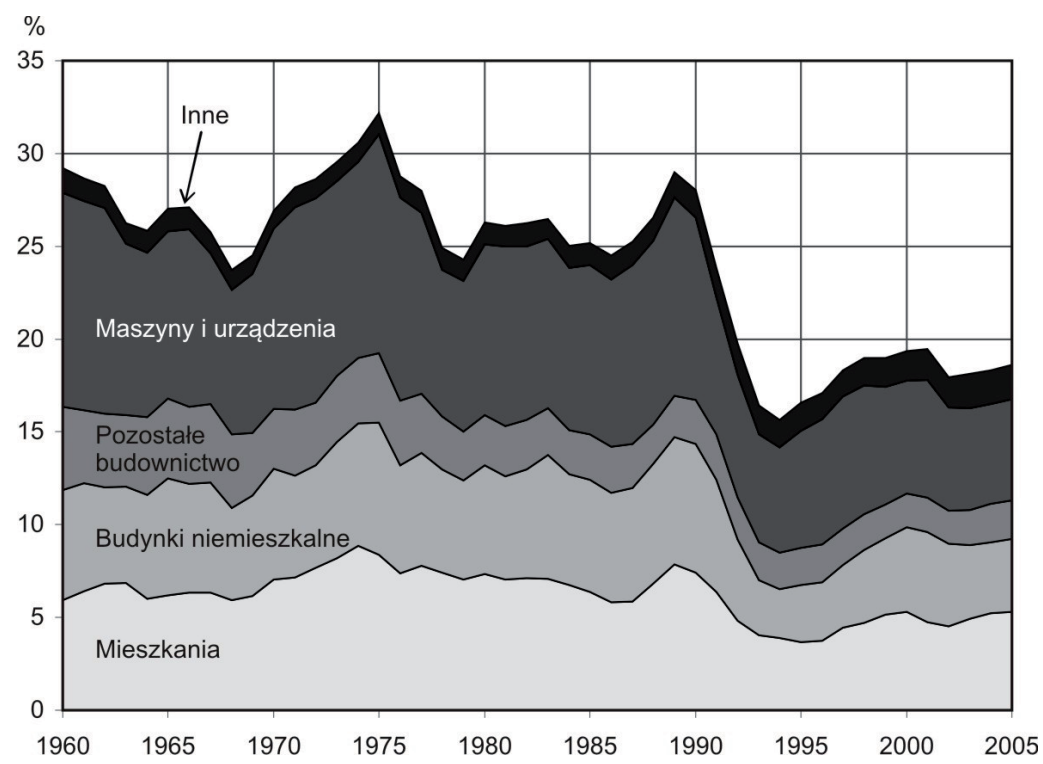

Ryc. 1. Nakłady brutto na środki trwałe (inwestycje)

w Finlandii w latach 1960-2005 w relacji do PKB

Źródło: Kiander i in. (2006, s. 13)

Kolejny etap rozwoju to gospodarka oparta na wiedzy. W Finlandii przejście do gospodarki opartej na wiedzy związane było z pojawieniem się i intensywnym rozwojem sektora ICT pod koniec lat 80. Jednak technologie i produkty ICT związane były dość silnie z tradycyjnymi przemysłami drzewnym i metalowym. Przemysł elektroniczny zaczął rozwijać się w latach 60. poprzez dostarczanie i rozwijanie technologii kontroli produkcji, automatyzacji 


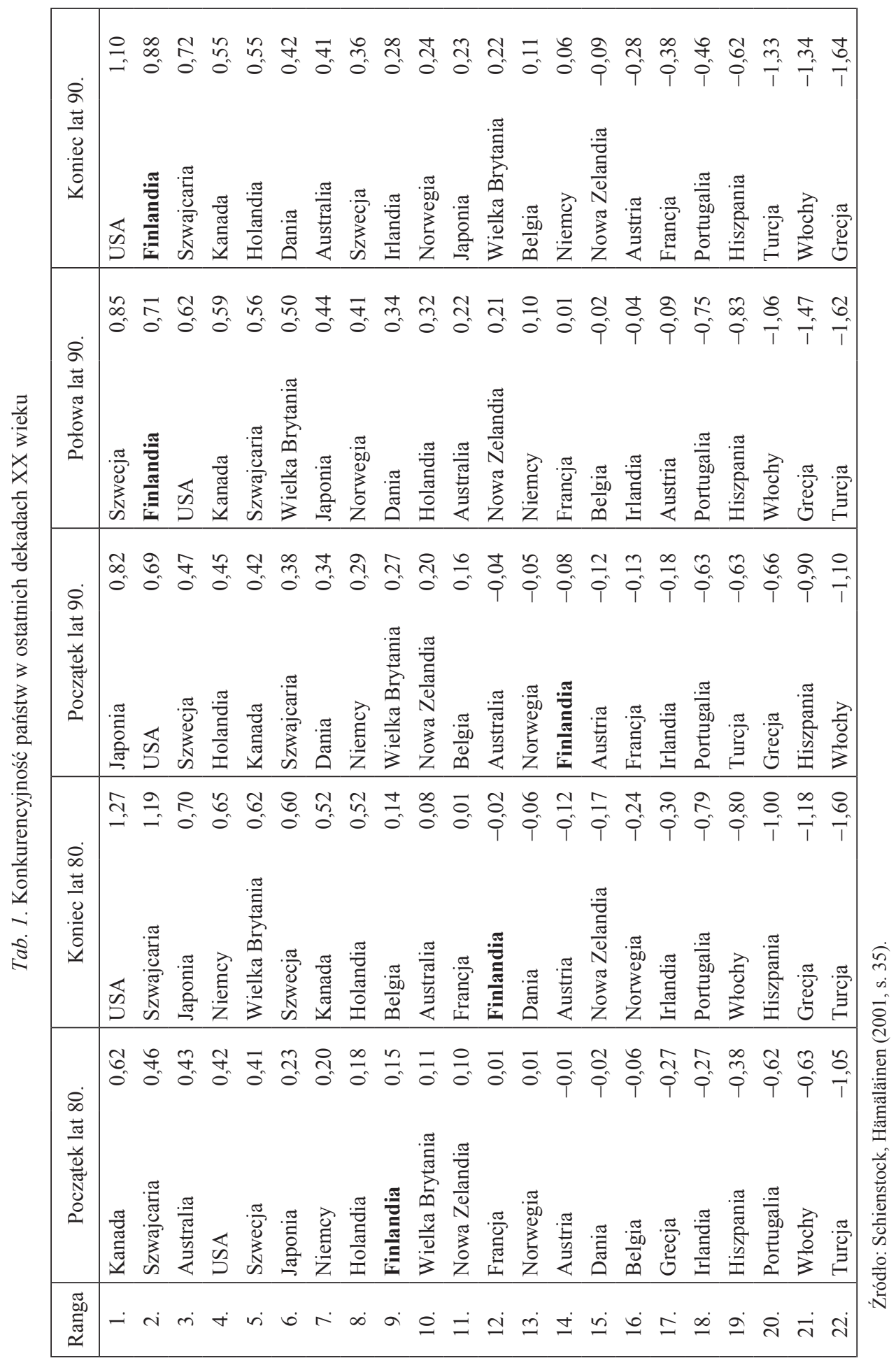


fabryk i przesyłania informacji dla kluczowych branż, mających największe znaczenie dla eksportu. Rosnące zapotrzebowanie na bardziej efektywne metody produkcji wpłynęło na rozwój innowacji opartych na rodzimych rozwiązaniach i badaniach. To doprowadziło do „twórczej destrukcji” fińskiego przemysłu tradycyjnego, w której innowacje „niszczyły” dotychczasowe technologie i metody produkcji, wypierając je produktami o nowych, bardziej efektywnych konfiguracjach (Maliranta 2004). Ważnym aspektem tego stadium industrializacji było również otwieranie się gospodarki, kiedy to rozwinęła się internacjonalizacja produkcji (Mannio i in. 2003). W tym czasie zmieniły się znacznie kierunki polityki gospodarczej. Polityka zorientowana na innowacje i rozwijanie nowych technologii stała się dominująca. Zmieniło się również podejście do polityki gospodarczej - przestała być ona tylko interwencją w mechanizmy rynkowe i zaczęła zmierzać w kierunku tworzenia i ulepszania nowych, bardziej złożonych czynników wytwórczych, takich jak wiedza, kreatywność i innowacyjność. Istotnym aspektem była również poprawa ogólnych warunków prowadzenia działalności gospodarczej.

Udane budowanie gospodarki na wiedzy, które odbywało się między innymi poprzez rozwój przemysłów zaawansowanej technologii, miało istoty wpływ na międzynarodową pozycję konkurencyjną Finlandii. Schienstock i Hämäläinen (2001) wyznaczyli konkurencyjność gospodarek krajów OECD i jej zmiany w dwóch ostatnich dekadach XX w. Na pozycję konkurencyjną $\mathrm{w}$ tym badaniu wpływały przede wszystkim poziom i możliwości rozwoju gospodarki opartej na wiedzy. Ogólny wskaźnik konkurencyjności składał się z siedmiu działów, opisywanych przez wskaźniki szczegółowe. Do działów tych należą: (1) nowe zasoby produkcyjne (kapitał ryzyka, kapitał ludzki, wiedza naukowa, infrastruktura informatyczna), (2) nowe technologie (B+R, innowacje, adaptacja ICT), (3) nowe sposoby organizacji, (4) cechy nowych produktów (złożoność popytu, współpraca użytkownik-producent), (5) stopień umiędzynarodowienia (inwestycje zagraniczne, handel międzynarodowy, międzynarodowe alianse strategiczne), (6) zachęty instytucjonalne (podatki, regulacje), (7) rola rządu (wydatki na poprawę wydajności i konkurencyjności, stopień redystrybucji dochodu). Wartości wskaźnika konkurencyjności dla każdego z działów zostały obliczone jako średnia ważona kilku znormalizowanych wskaźników, co umożliwiło porównywanie różnych aspektów konkurencyjności. W latach 80. ogólna konkurencyjność Finlandii pogorszyła się, co spowodowało spadek w rankingu z 9 na 14 miejsce wśród krajów 22 krajów OECD. Jednak od połowy lat 90. pozycja ta uległa gwałtownej zmianie i Finlandia stała się jedną z najbardziej konkurencyjnych gospodarek (tab. 1). To pokazuje, jak rozwój branż wytwarzających i wykorzystujących zaawansowane technologie wpływa na konkurencyjność całej gospodarki.

\section{ZNACZENIE PRZEMYSŁU ZAAWANSOWANYCH TECHNOLOGII I SEKTORA ICT} W GOSPODARCE FIŃSKIEJ

Postępująca specjalizacja fińskiej gospodarki w wytwarzaniu dóbr i usług o wysokim nasyceniu wiedzą współwystępowała wraz z procesem stopniowego otwierania się gospodarki i deregulacji przepływów finansowych. Charakterystyczną cechą przypadku fińskiego jest nietypowa ścieżka industrializacji kraju. Nie dość, że proces ten zaczął się później niż w innych krajach europejskich (połowa XX w.), to przebiegał niezwykle dynamicznie i spo- 
wodował przejście od gospodarki opartej na zasobach naturalnych do wyspecjalizowanej produkcji urządzeń mechanicznych, elektroniki, a przez to także dalej do rozwoju inżynierii i technologii informacyjno-komunikacyjnych. Niewiele jest przykładów tak szybkiego uprzemysłowienia i transformacji strukturalnej gospodarki z bogatymi zasobami naturalnymi w gospodarkę o znacznym wykorzystaniu wiedzy i wysoko wyspecjalizowanym przemyśle. Rozwój przemysłu zaawansowanej technologii i sektora ICT w latach 90. spowodował ponowną industrializację, przez co Finlandia jest krajem o względnie wysokim udziale przemysłu w gospodarce i słabym rozwoju usług, jak na współczesne tendencje występujące w gospodarce światowej (ryc. 2). Zarówno zatrudnienie, jak i wartość dodana w przemyśle rosły szybciej niż np. w usługach. Przykładowo, w latach 1990-2007 wartość dodana w przemyśle wzrosła o $140 \%$, podczas gdy w usługach o $40 \%$.

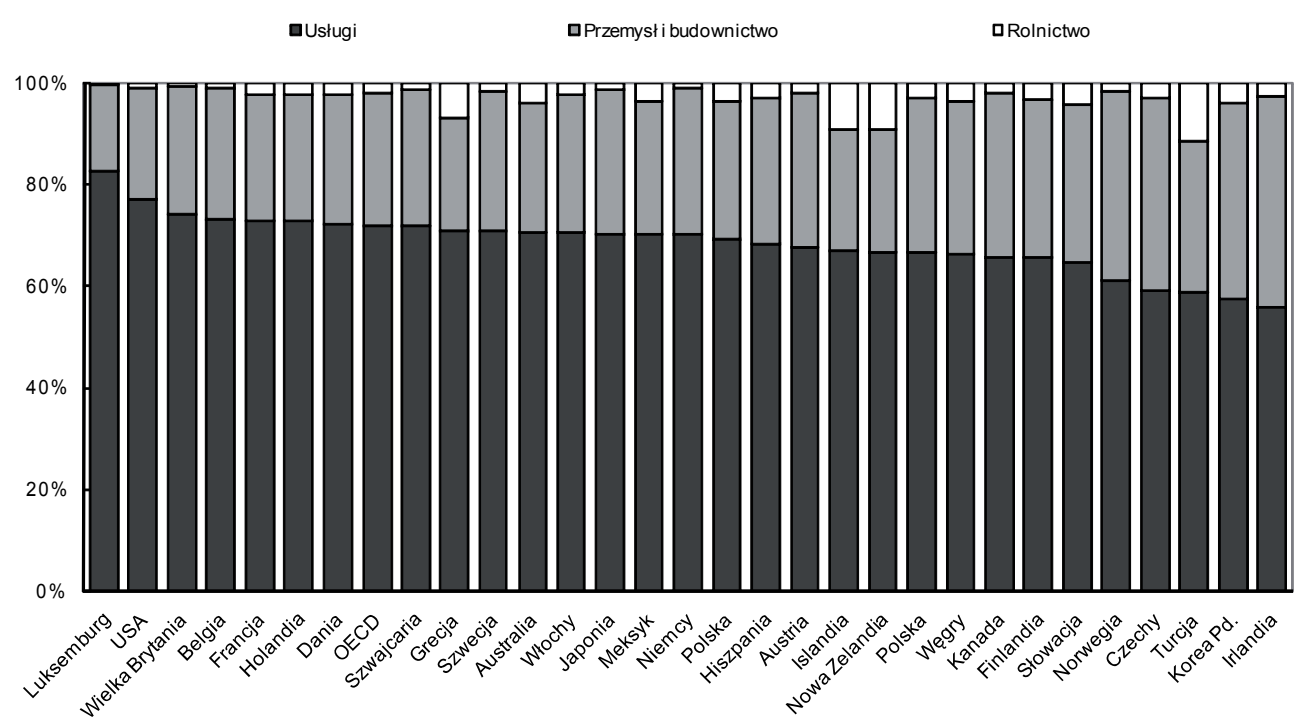

Ryc. 2. Struktura gospodarek państw OECD - udział usług, przemysłu i rolnictwa w wartości dodanej ogółem w 2002 roku

Źródło: OECD (2005, s. 169)

Rozwój przemysłowy Finlandii nie byłby możliwy, gdyby nie liberalizacja handlu i znoszenie ograniczeń związanych z przepływami kapitałowymi w latach 90. Decyzje rządu w tym zakresie ułatwiły działalność inwestycyjną, w szczególności napływ kapitału zagranicznego. Te zmiany miały istotne znacznie dla przyszłej ścieżki rozwoju w kierunku gospodarki opartej na wykorzystaniu zaawansowanych technologii, w szczególności informacyjno-komunikacyjnych. Ich efektem było zwiększenie inwestycji w wiedzę, a w szczególności wydatków na $\mathrm{B}+\mathrm{R}$. Choć publiczne fundusze na $\mathrm{B}+\mathrm{R}$ rosły, to jednak ich względny udział w ogólnych wydatkach zmniejszał się. Charakterystyczny dla gospodarki fińskiej jest wysoki i rosnący udział firm prywatnych w nakładach na badania i rozwój, który w 2007 roku wynosił 71\%, podczas gdy w roku 1995 stanowił 63\% ogółu wydatków.

Wzrost ten jest przypisywany głównie działalność Nokii. Pomimo że jest wiele innych firm ICT, to właśnie Nokia jest motorem rozwoju całego sektora jak i gospodarki. 
W 2003 roku udział Nokii w wydatkach na B+R sektora prywatnego wynosił 40\%, udział w PKB kraju 3,3\%, eksport firmy stanowił 20\% eksportu Finlandii, a zatrudnienie (wraz z pracownikami firm kooperujących) stanowiło 5\% ogólnego zatrudnienia (Gergils 2006, s. 175). Jednakże pomimo dominującej pozycji w strukturze fińskiej gospodarki, rozwój i sukces Nokii jest również wynikiem zmian zachodzących w przemyśle i gospodarce kraju. Nokia w latach 90. była (i nadal jest) największym beneficjentem fińskiego systemu innowacji (Ali-Yrkkö, Hermans 2002). Niemniej jednak wkład firmy w przemiany strukturalne, a w szczególności w rozwój przemysłu elektronicznego w latach 90., jest nie do przecenienia (zob. ryc. 3). Niezwykle dynamiczny rozwój działalności związanych z sektorem teleinformatycznym spowodował w latach 1991-2002 blisko dziewięciokrotne zwiększenie jego produkcji, a także wzrost udziału w strukturze gałęziowej przemysłu do 22\% w 2004 r. (ryc. 4).

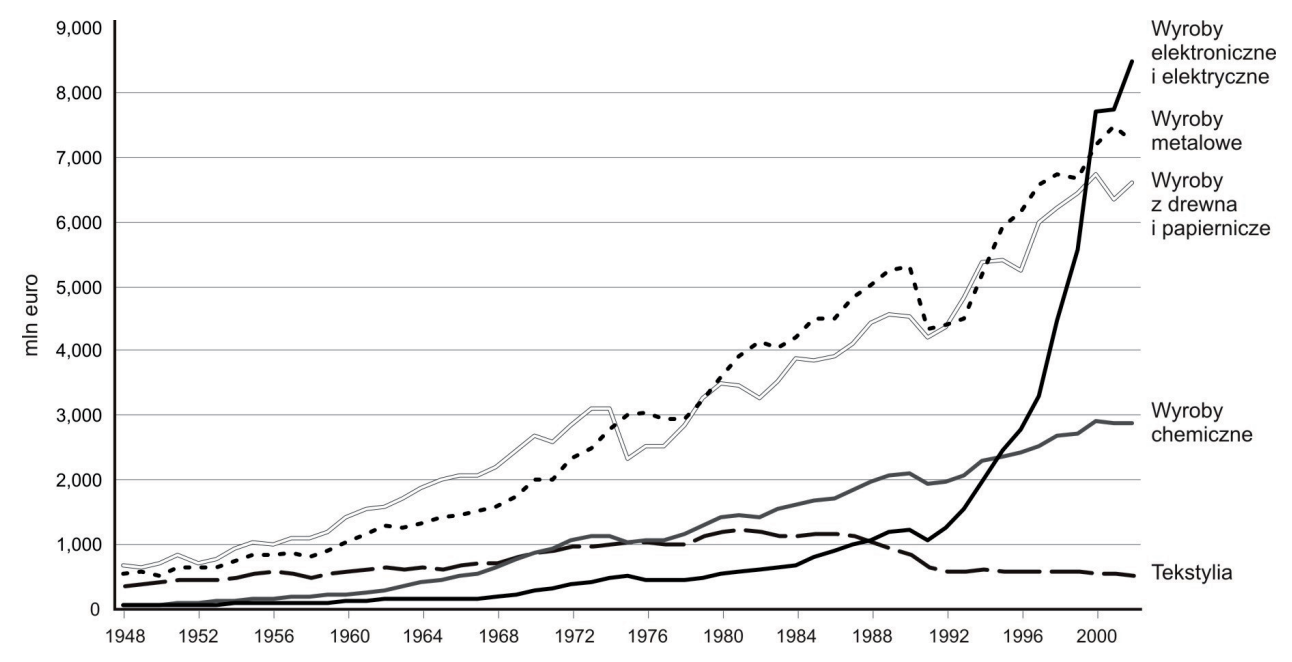

Ryc. 3. Produkcja przemysłowa w Finlandii w latach 1948-2002 (wg cen z roku 2000)

Źródło: Rouvinen, Ylä-Anttila (2004, s. 89)

Oprócz Nokii istotne znaczenie dla przemian w fińskim przemyśle miała polityka władz, w szczególności polityka przemysłowa i innowacyjna. Już na przełomie lat 60. i 70. ubiegłego wieku pod wpływem rewolucji naukowo-technologicznej polityka rozwojowa kraju zaczęła koncentrować się na przemysłach elektrotechnicznym i elektronicznym, oscylując coraz wyraźniej w kierunku technologii informacyjnych i telekomunikacji. Proces ten, konsekwentnie kontynuowany w latach 70. i 80., nabrał przyspieszenia w pierwszej połowie lat 90. Jego ukoronowaniem stała się przyjęta w 1995 roku strategia przechodzenia kraju do stadium społeczeństwa informacyjnego, kładąca nacisk na: rozwój technologii informacyjnych i infrastruktury informacyjnej jako materialnej podstawy społeczeństwa informacyjnego, świadome kształtowanie warunków sprzyjających wdrażaniu gospodarki opartej na wiedzy oraz działania na rzecz przygotowania mieszkańców Finlandii do życia w warunkach społeczeństwa informacyjnego (Wierzbołowski 2003).

Głównym celem polityki przemysłowej Finlandii jest zapewnienie wzrostu gospodarczego, poprawa sytuacji na rynku pracy i dywersyfikacja struktury produkcyjnej. Jednym 
z ważniejszych jej aspektów jest ścisłe powiązanie polityki przemysłowej z polityką naukową i polityką rozwoju technologicznego. Ponadto polityka ta opiera się na koncepcji skupień branżowych, a więc segmentów gospodarki, w skład których wchodzą współzależne przemysły połączone ze sobą różnego rodzaju powiązaniami produkcyjnymi, technologicznymi, w sferze prac B+R itd., a także współpracujące z tymi przemysłami organizacje naukowe, projektowe itp. (Steinbock 2004; TIEKE 2006). Sama polityka naukowa zapewnia sprzężenia zwrotne do polityki przemysłowej, tym bardziej że jednym z zadań polityki naukowej jest identyfikowanie obszarów przemysłowego rozwoju i związanych z tym nowych potrzeb społecznych. Ponadto otwiera przed państwem nowy obszar interwencjonizmu państwowego: nakłady ze środków publicznych na rozwój nauki, badania podstawowe i prace $\mathrm{B}+\mathrm{R}$ dokonywane sa selektywnie z myślą o wspomożeniu celów zarysowanych w polityce przemysłowej.

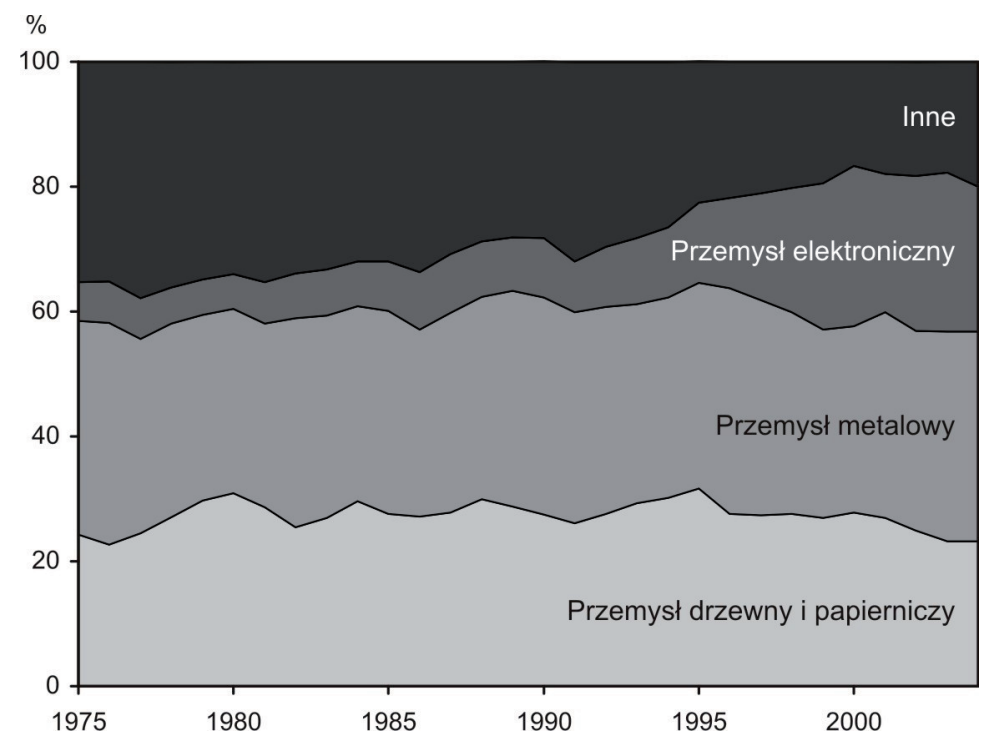

Ryc. 4. Główne gałęzie przemysłu Finlandii w latach 1975-2004 (jako \% wartości dodanej w przemyśle)

Źródło: Kiander i in. (2006, s. 26)

Przemiany społeczno-gospodarcze, które doprowadziły to rozwoju przemysłów zaawansowanej technologii i sektora ICT, związane były zarówno z ewolucją gospodarki, jak i sytuacją geopolityczną kraju. Po II wojnie światowej Finlandia pozostawała w bliskich z konieczności - związkach z wielkim wschodnim sąsiadem Związkiem Radzieckim. Upadek ZSRR i załamanie gospodarki w dawnym imperium spowodowało najgłębszy w powojennej historii kraju kryzys gospodarczy. Produkcja przemysłowa w 1994 roku spadła o 10\%, a bezrobocie wzrosło do $20 \%$. Kryzys ten został jednak szybko pokonany dzięki sprawnej polityce rządu, która objęła m.in. dewaluację fińskiej marki, co wpłynęło korzystnie na podniesienie konkurencyjności cen krajowych produktów. Przystąpienie Finlandii do Unii Europejskiej w 1995 roku również przyczyniło się do poprawy sytuacji gospodarczej. Jednak szczególny wpływ na przeobrażenia gospodarcze miał rozwój działalności związanych z wytwarzaniem 
i ulepszaniem nowych technologii. Sektor teleinformatyczny, związany z technologiami informacyjno-komunikacyjnymi, stał się głównym źródłem wzrostu w okresie po kryzysie. Przykładowo, w stołecznym regionie Helsinek w połowie lat 90. wzrost zatrudnienia nastapił zwłaszcza w działalnościach związanych z ICT. Liczba zatrudnionych w sektorze tym zaczęła rosnać już od 1993 roku, podczas gdy w innych branżach dopiero w 1995. W roku 1997 liczba pracujących w sektorze ICT była o 40\% wyższa niż w 1993 roku, a obroty firm tego sektora stanowiły jedną piątą obrotów wszystkich firm w regionie (Vaattovaara, Kortteinen 2003). Podobnie udział sektora w całej gospodarce był zauważalny. Pod koniec lat 90. produkty ICT stanowiły jedną piątą eksportu Finlandii, a środki przeznaczane na ich ulepszanie stanowiły połowę wydatków firm na B+R (ryc. 5). Rozwój przemysłu zaawansowanej technologii okazał się więc skuteczną receptą na szybkie wyjście z kryzysu.

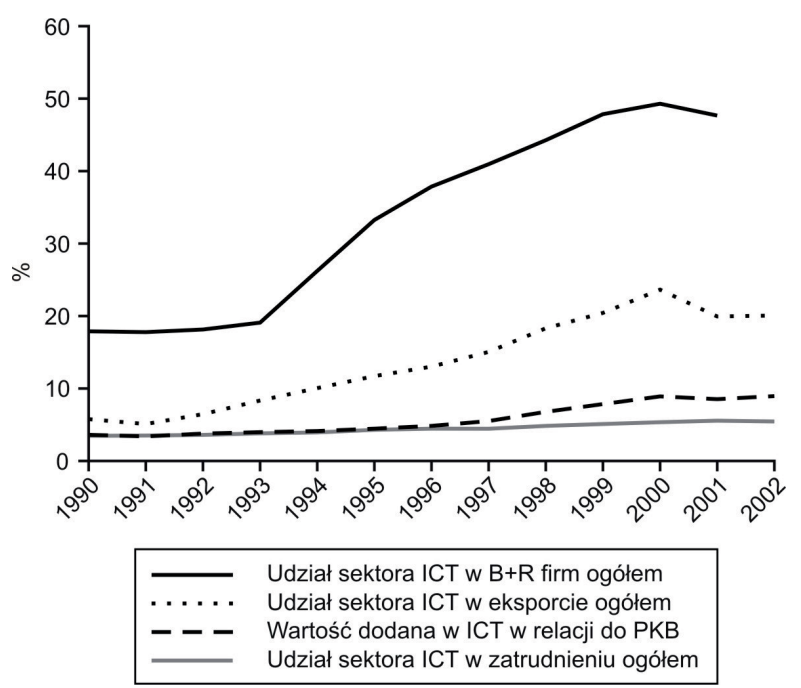

Ryc. 5. Znaczenie sektora teleinformatycznego (ICT) w Finlandii w latach 1990-2002 Źródło: Dahlman i in. (2006, s. 22)

\section{ZAKOŃCZENIE}

Dekady względnie stałego otoczenia politycznego i gospodarczego w Finlandii oraz jednolita i spójna wizja rozwoju gospodarki były niewątpliwie ważnymi czynnikami sukcesu tego kraju. Procesy rozwoju gospodarczego Finlandii w ostatnich dwóch dekadach uważane są za niezwykle udane (Oinas 2005; Porter 1998, 2004). Rozwój ten związany był z intensywną restrukturyzacją i modernizacją gospodarki, a w efekcie przejściem z gospodarki opartej na eksporcie zasobów naturalnych do rozwiniętej technologicznie gospodarki opartej na wiedzy. Według Portera (1990) czynniki niekorzystne mogą być zamienione w źródła przewagi konkurencyjnej. Choć czynników, które odegrały istotną rolę w tych procesach, było kilka, jednym z nich był rozwój przemysłu zaawansowanej technologii i sektora teleinformatycznego. $Z$ jednej strony były to czynniki strukturalne związane $\mathrm{z}$ in- 
dustrializacją i modernizacją tradycyjnej gospodarki, a z drugiej te o charakterze instytucjonalnym, tworzące sprzyjające otoczenie do rozwoju. Czynniki instytucjonalne miały szczególne znaczenie w budowie gospodarki opartej na wiedzy - umożliwiły szybkie i skuteczne przemiany. Do czynników instytucjonalnych wpływających na rozwój gospodarki opartej na wiedzy, w tym również przemysłu zaawansowanej technologii i sektora ICT, zaliczyć można takie elementy, jak polityka państwa i finansowanie rozwoju wiedzy, odpowiednie struktury instytucjonalne w postaci organizacji wspierających wytwarzanie i wykorzystanie wiedzy, zdeterminowane instytucjonalnie formy organizacji działalności innowacyjnej, a więc sieci współpracy i skupienia, fiński model państwa dobrobytu oraz nieformalne instytucje związane z kulturą ekonomiczną i klimatem społecznym (Stachowiak 2008). Te czynniki w powiązaniu z konsekwentnym rozwojem zasobów ludzkich oraz działalności związanych z wytwarzaniem i wykorzystaniem zaawansowanych technologii pozwoliły osiągnąć poziom rozwoju zbliżony do najlepiej rozwiniętych państw.

Finlandia zbudowała szczególnie korzystne otoczenie, które pozwoliło na dynamiczny rozwój gospodarki w oparciu o zaawansowane technologie. Choć w pierwszej dekadzie XXI w. rozwinęły się nowe branże przemysłu zaawansowanej technologii, to ciągle specjalizacja gospodarki fińskiej opiera się na działalności związanej z ICT, a w szczególności z komunikacją mobilną. O ile przez całe dziesięciolecia XX w. Finlandia pozostawała w tyle, jeśli chodzi choćby o procesy industrializacji i była krajem „goniącym” czołówkę, teraz zajęła pozycję lidera. Sukces ten osiągnęła dzięki wykorzystaniu zaawansowanych technologii, których ewolucja zależna była nie tylko od globalnych tendencji i ogólnych przemian strukturalnych, ale również od specyfiki dotychczasowego rozwoju danej gospodarki.

\section{Literatura}

Ali-Yrkkö J., Hermans R., 2002, Nokia in the Finnish innovation system. ETLA Discussion Papers, 811, ETLA - The Research Institute of the Finnish Economy, Helsinki.

Castells M., Himanen P., 2002, The information society and the welfare state: The Finnish model. Oxford University Press, New York.

Dahlman C.J., Routti J., Ylä-Anttila P., 2006, Finland as a knowledge economy: Elements of success and lessons learned, World Bank, Washington.

Gergils H., 2006, Dynamic innovation systems in the Nordic countries? Denmark, Finland, Iceland, Norway and Sweden, SNS, Stockholm.

Kiander J., Kröger O., Romppanen A. red., 2006, Finnish economy: Structural indicators, Government Institute for Economic Research, Helsinki.

Maliranta M., 2004, Creative destruction in Finnish manufacturing, Finnish Economy and Society, 1, s. $97-101$.

Mannio P., Vaara E., Ylä-Anttila P. red., 2003, Our path abroad: Exploring post-war internationalization of Finnish corporations, Taloustieto, Helsinki.

OECD, 2005, OECD Science, technology and industry scoreboard, OECD, Paris.

Oinas P., 2005, Finland: A success story? European Planning Studies, 13, 8, s. 1227-1244.

Ojala J., Eloranta J., Jalava J. red., 2006, The road to prosperity: An economic history of Finland, Suomalaisen Kirjallisuuden Seura, Helsinki.

Porter M.E., 1990, The competitive advantage of nations, Macmillan, London.

Porter M.E., 1998, The competitive advantage of nations - the Finnish case, [w:] D. Steinbock red., The competitive advantage of Finland: From cartels to competition?, Taloustieto, Helsinki.

Porter M.E., 2004, Global competition, clusters and Finland's Wireless Valley, [w:] D. Steinbock red., What Next? Finnish ICT cluster and globalization, Ministry of Interior, Helsinki, s. 13-17. 
Rouvinen P., Ylä-Anttila P., 2004, Little Finland's transformation to a wireless giant, [w:] S. Dutta, B. Lanvin, F. Paua red., The global information technology report 2003-2004: Towards an equitable information society, Oxford University Press, New York, s. 87-108.

Schienstock G., Hämäläinen T., 2001, Transformation of the Finnish innovation system: A network approach, Sitra Reports, 7, Sitra, Helsinki.

Stachowiak K., 2008, Czynniki instytucjonalne w budowaniu i funkcjonowaniu gospodarki opartej na wiedzy - przykład Finlandii, [w:] J.J. Parysek, T. Stryjakiewicz red., Region społeczno-ekonomiczny i rozwój regionalny. Bogucki Wydawnictwo Naukowe, Poznań, s. 121-151.

Steinbock D., 2004, What next? Finnish ICT cluster and globalization, Ministry of Interior, Helsinki. TIEKE, 2006, ICT Cluster Finland Review 2006. TIEKE - Finnish Information Society Development Centre, Helsinki.

Vaattovaara M., Kortteinen M., 2003, Beyond polarisation versus professionalisation? A case study of the development of the Helsinki region, Finland, Urban Studies, 40, 11, s. 2127-2145.

Wierzbołowski J., 2003, Fińska droga do społeczeństwa informacyjnego i gospodarki opartej na wie$d z y$, Instytut Łączności, Warszawa.

\section{Evolution of the high-tech industry and the ICT sector in Finland}

The paper presents in a broad outline the main characteristics of the evolution of the Finnish high-tech industry and ICT sector within the context of general changes in industry and the national economy. In the last decades of the 20th century Finland dynamically developed a knowledge-based economy and became one of the leaders of the information society. A spectacular manifestation of this is the position of the country in global competitiveness rankings, where Finland has occupied a top position for several years, sometimes even being ahead of the United States. The so-called 'Finnish model of information society' is characterised, among others, by a significant growth in knowledge-intensive industries and a complex system of research and development support. However, all those changes were dependent on the previous development path of the country. The structure of Finnish industry was rather one-sided until the $1980 \mathrm{~s}$, when knowledge- and expertise-intensive production started to catch up with the level of manufacturing dominated by raw materials, capital and energy. For a long time, Finland specialised in the forest industry and in the processing of metals. A new sector that has developed during the past decades is electronics and, especially, the manufacturing of communication devices. Furthermore, the economy has changed more dramatically in Finland than in any other developed country over the same period of time. Industries have become technology-intensive and production is strongly characterised by specialisation. Finland has become the most specialised country in information and communication technology in the world, and this specialisation trend is continuing. The forest industry and other traditional industries rely more and more on the new technologies and state-of-the-art knowledge. In Finland, industrialisation started later than in other countries, but it was very rapid. Industrial production and exports grew faster than the rest of the economy in the $1990 \mathrm{~s}$, and the structure of exports diversified. Unlike other developed countries, Finland "re-industrialised" in the 1990s. The contribution of industry to the total volume of production and employment has been higher in Finland than in other advanced economies in the past couple of years.

dr Krzysztof Stachowiak

Uniwersytet im. Adama Mickiewicza w Poznaniu

Instytut Geografii Ekonomicznej i Gospodarki Przestrzennej

e-mail: krst@amu.edu.pl 